\title{
A magyar nyelvújítás és Kazinczy második Orthologus és Neologus...--a*
}

1. Kazinczy tanulmánya mint mérföldkő. KAZINCZY FERENC Orthologus és Neologus; nálunk és más Nemzeteknél címü tanulmánya határpontnak számít a magyar nyelvújítás történetében. Nyelvészek és irodalomtörténészek különböző szempontok alapján értenek egyet ebben (BALASSA 1904; BíRÓ 2010; CSETRI 1990; DÖMÖTÖR 2003, 2006; HORVÁTH 1956; RUZSICZKY 1963; SZEMERE 1974; TOlCSVAI NAGY 2007; TOLNAI 1929: 137; ZsILINSZKY 2003: 96). A közoktatásban is érvényes tudományos narratíva szerint a tanulmány zárópontot jelent, amely végső soron a magyar irodalmi nyelv és ezen keresztül a magyar köznyelv sikeres megújulását eredményezte. Csak az utóbbi években derült fény arra, hogy ezt a kánont formáló tanulmányt KAZINCZY visszavonta, s helyette másik írást szánt a nyilvánosság elé.

Az Orthologus és Neologus...-nak számos - jórészt töredékes - variánsa létezik, amelyek összesen kb. 10 ívnyi terjedelmüek. Két teljesen kompakt változatot ismerünk: az elsőt 1819. augusztus 15 -én zárta le a szerző, a másodikat 1819. november 5-én. Az augusztusi szöveg a 19. század első magyar nyelvü tudományos folyóiratában, a Tudományos Gyüjteményben jelent meg 1819 novemberében (KAZINCZY 1819a). A második dolgozat egészen 2013-ig nem látott nyomdafestéket (KAZINCZY 2013). Az elmúlt kétszáz évben az Orthologus és Neologus...-nak a visszavont, de megjelent változata állt a kutatók érdeklődésének homlokterében. Annak ellenére, hogy a kéziratos szövegváltozatok létezése ismert volt, hiszen a hagyaték katalógusa említést tesz ezekről (GERGYE 1993: 61), furcsa módon eddig senki sem próbálkozott a szöveg újraolvasásával. Ez azért sajnálatos, mert a tanulmány kéziratos variánsai (KAZINCZY 1819b) új, elméleti szinten kikristályosodottabb beszédpozíciót rögzítenek, mint a Tudományos Gyüjteményben megjelent dolgozat.

Ebben a tanulmányban három kérdésre keresem a választ: 1. Miért írt új dolgozatot KAZINCZY? 2. Miben különbözik egymástól a két változat? 3. Hogyan befolyásolta volna a nyelvújítás történetét a második Orthologus és Neologus...?

2. Miért írta újra Kazinczy a tanulmányt? KAZINCZY azért fogott hozzá müve átdolgozásához, mert az túl rövid volt. Ennél több mondanivalója lett volna, de arról értesült, hogy a folyóirat két ívnél terjedelmesebb írást nem publikál (Levele Döbrenteinek, KazLev. 1907: 26-27). Elsősorban terjedelme miatt nem volt megelégedve tehát szövegével (Levelei többeknek, KazLev. 1907: 58, 79, 140), bővebben szeretett volna fogalmazni, de ezt a körülmények nem tették lehetővé.

* Jelen tanulmány a Magyar Nyelvtudományi Társaság 2015. november 10-i felolvasó ülésén elhangzott előadásnak rövidített változata. A tanulmány a Bolyai János Kutatási Ösztöndíj támogatásával készült. A szerző a Debreczeni Attila vezetése alatt működő, MTA-DE Klasszikus Magyar Irodalmi Textológiai Kutatócsoport alkalmazottja. 
Eszerint olyan részek kerültek bele a második változatba, amelyeknek nagy fontosságot tulajdonított, így a módosítás tartalmi bővítésnek is tekinthető.

Ebben az időszakban több gondolkodóval számos fórumon (leveleiben, folyóirat-közleményekben és nyomtatványokon) teoretikus vitában állt. Érthető, ha elveit minél tisztább érveléssel, minél félreérthetetlenebbül kívánta vitapartnerei és a közvélemény elé adni. A helyzetét nehezítette, hogy több névtelen írásra is reagálni kívánt, de azok szerzőit nem tudta azonosítani. A névtelenségbe burkolózó vitapartnerek nyomásként hatottak rá, s ennek kedvező következménye volt a dolgozat tartalmasabbá válása.

3. Miben különbözik a két változat? ${ }^{1}$ A szöveg első felében mindkét tanulmány szorosan egymás mellett halad, csupán néhány stilisztikai változtatás vagy bővítés figyelhető meg: itt a bekezdések mikroszerkezete alig különbözik egymástól. Ezért ezekkel a részletekkel itt nem foglalkozom. Három jelentősebb bővülésen ment keresztül a tanulmány. Mivel KAZINCZY éppen a rövidség miatt vonta vissza a korábbi szöveget, ezért ezekre az új elemekre fókuszálok.

Mindkét tanulmány a nyelvi változások keletkezésére mutat rá kezdő lépésként, és ebből a folyamatból, annak támogatóiból és ellenzőiből formálja meg a két tábor, az ortológus és a neológus csoport körvonalait. Mindkét fél a nemzetiség öszszetartó erejét tiszteli a magyar nyelvben, csakhogy az egyik oldal elutasítja a nyelvi változásokat, mert elfajzást lát bennük - a másik viszont keresi az újítást. (1-5.)

KAZINCZY a következő szakaszokban irodalomtörténetbe, és csak részben nyelvtörténetbe ágyazva ismertette az iskolák eredetét. Az irodalmi nyelv elömenetele szempontjából fontosnak ítélt szerzőket vette sorra a magyar nyelv fejlődési fázisainak bemutatásához, a nyelvemlék-irodalomtól kezdve a kortárs írókig. Ebben az eredettörténetben jelenik meg a nyelvújítás, mégpedig Bessenyei György, Báróczi Sándor, Barcsai Ábrahám, majd Baróti Szabó Dávid, Révai Miklós és Rájnis József költészetével. (10.) Ezek a sorok - amelyek rövidebben olvashatóak a Tudományos Gyüjteményben - két szempontból fontosak. A nyelvújítást a szépirodalom, pontosabban a költészet nyelvéhez kötik, s emellett szokatlan módon kitágítják a nyelvújítók táborát. Ezekben a szakaszokban KAZINCZY a szépirodalom, a költészet elemi ismertetőjegyének tekintette az újítást: minden író neológus tehát az okfejtésben.

Az írók csoportokra osztása során KAZINCZY a kéziratos szövegben új terminust vezetett be: az újítókat három csoportra osztotta - szemben a nyomtatott szöveggel, ahol még csak két tábor van megnevezve. (13.) Az első csoport szélsőségesen xenologizál, a második latinizál (,a’ deák szín lepte-el írásaikat”), de nem a klasszikus latin szerint - ez valószínúleg az egyházi latinságra utal -, a harmadik tábor pedig minden külföldi mintától mereven elzárkózik. A három iskolához viszonyítva KAZINCZY középre orientálódik (13.). Az itt körvonalazott iskola a másik kettőtől különböző metairányzat, amelyet a kéziratos változatban syncretismus-nak nevezett el (de egyelöre törölt a fogalmazványból). Ez a csoport

\footnotetext{
${ }^{1}$ Az itt következő szakaszok átveszik az alábbi szöveg adatait és követik annak gondolatmenetét: CZIFRA 2013: 141-164. A föszövegben olvasható zárójeles arab számok a hivatkozott könyv Függelékében közölt párhuzamos szövegkiadás bekezdéseire utalnak.
} 
a későbbiekben fontos szerephez fog jutni. Minimális terjedelmü, de jelentős eltérést mutat már a felütésben a kéziratos szöveg.

3.1. A jelentős terjedelmü eltérés ez után a szakasz után következik. (30-41., 45-61.). Ez azt jelenti, hogy a Tudományos Gyüjteményben közzé tett szövegnek nemcsak a vége, hanem a középső része is átdolgozásra került. Ezekben a bekezdésekben KAZINCZY a történeti szálat folytatva a neológia túlbillenéséről ír, amely teljes természetességgel vezet a másik oldal ellenállásához. Az egyensúly helyreállítására vállalkozva tünik fel a történetben az ortológia tábora. (30.)

Az ortológusokról egyelőre két dolgot tudunk meg: hogy elveiket véghezvinni a magyar nyelv kárára válna (32.), és egy egyelőre homályosabb tételt, ti. hogy nem lehetséges a nyelvet pusztán grammatikai szempontból megközelíteni: „És ha az vallatik igaznak, a' mit az Analyt. Grammatica tanít, mit fogunk ítélni, mit kell ítélnünk a' Virág', a' Kis', a' Himfy', a' négy Horváth', a’ Döbrentei', a' Berzsenyi', Szemere', Kölcsey', Szent-Miklósy', Ungvár-Németi Tóth’ dolgozásaik felől??" (33.) KAZINCZY arra utal, hogy VERSEGHY FERENC grammatikájának (VERSEGHY 1816) szempontjait kíméletlenül érvényesítve a kortárs írók müvei nem ütnék meg a nyelvi helyesség mércéjét. Ezzel a grammatikai szempontú megközelítéssel közelebb kerülünk az ortológia megismeréséhez, amelyhez további, a nemzeti akadémiák tevékenységét ismertető szakaszok is hozzásegítenek. A nyelv egy olyan organikus rendszerként jelenik meg, amely evolúciószerüen fogja kiforrni a kívánt nyelvállapotot; ebben viszont jelen állapotában akadályoznák a szabályok. Amiképpen az olasz és a francia akadémia nem szolgálta a nemzeti nyelv javát, úgy a magyar nyelvi törvényhozó testülettől is elzárkózik KAZINCZY, hiszen regulatív elemek a nyelvfejlődés ezen szakaszán káros befolyással lehetnek a magyar nyelvre. (35-36.).

Az ortológusok táborának további leírása a nyelvújítók elleni vitairatok felsorolásával folytatódik. Itt végre fény derül arra - amelyről a nyomtatott szöveg egyetlen szót sem ejt -, hogy kiket sorol KAZINCZY ebbe a csoportba: BEREGSZÁSZI NAGY PÁl könyve (BEREGSZÁSZI 1815), SOMOGYI GEDEON Mondolata (NÉV NÉLKÜL 1813), SíPOS JÓZSEF Ó és újj magyar címü múve jelölik ki az elméleti határokat ([SíPOS] 1816). (37.) Rajtuk kívül még két név jelenik meg a listán, VERSEGHYé és FÜREDI VIDÁé ([VERSEGHY] 1816, FÜREDI 1818). (37.)

A nevek SOMOGYI GEDEONt leszámítva egytől egyig grammatikusok nevei. Múveik - ha FÜREDI VIDÁt KAZINCZY nyomán VERSEGHYvel azonosítjuk - szintén mind nyelvészeti munkák. Ezek az írók az említett munkáikban (és nem máshol, hiszen KAZINCZY is elismeri: verseiben például VERSEGHY is él újításokkal) elvetik a szóalkotást, a régi és a nyelvjárási szavakat, elutasítják a tükörfordításokat, és az idegen nyelvü példáktól általánosságban is tartózkodnak. (38.) Eljárásmódjukat az imént negatívumai által bemutatott francia akadémikusokhoz hasonlítja, és utal az olasz akadémiára is. (38.) Úgy véli a nyelv változtatásának kizárólagos jogát vindikálják maguknak ezek a szerzők.

A szakaszok felbukkannak a Tudományos Gyüjteményben is, de sokkal rövidebben. (17-29.) Kimarad az ortológusok színre lépésének nyelvtörténeti indoklása, hiányzik az akadémiai kezdeményezés bemutatása és hiányzik a névsor. Vagyis az ortológus tábor egyrészt sokkal kevesebb attribútummal van ellátva, másrészt 'nem 
újító'-ként definiálódik A kéziratos tanulmányban viszont a kontextusba került nyelvészeti mủvek, valamint a szerzők alapján az ortológusok inkább volnának grammatikusoknak nevezhetők. KAZINCZY az ortológusok nézeteit VERSEGHY elméleti írásai alapján foglalja össze, amelyben a tisztán érthetőség a nyelv legfontosabb kritériuma, és az ízlés nem releváns szempont a nyelv területén, mert az szubjektív nézőpontok alapján érvényesül, s ez a vélemények anarchiájára vezet. (41.) Úgy véli, ezek az írók „társaságként”, intézményesült formában kívánják a nyelvi egységesülést elérni. KAZINCZY az ortológia definícióját kéziratban nem a nyelvi újitások elvetése alapján határozza meg. Jellegzetességük inkább az egységre való törekvésben, vagyis a nyelvhasználat központosított regularizálásában ragadható meg.

A nyomtatott szöveg értelmezését nehezíti, hogy nem nevezi néven az ortológusokat, de mint létező személyekről ír róluk, és mint létező gyakorlatot mutatja be elveiket. (26.) Az Orthologus és Neologus... interpretálása során nem lehet azzal magyarázni az ortológus tábor körvonalazódásának hiányát, hogy minden író újít. A neológia nem bekebelezi a másik oldalt, hanem egyszerüen más szempontok alapján kerül meghatározásra. Ez burkoltan ugyan, de fellelhető a nyomtatott szövegben is. (27.) Az ortológusok eszerint nem tesznek különbséget a stílusnemek között, nem veszik tekintetbe a nyelv vízszintes és függőleges rétegzettségét. Amennyiben táborukat KAZINCZY utalásait követve SOMOGYI GEDEONra és a grammatikusokra szükítjük (a meg nem jelent szakaszban legalábbis a Mondolaton kívül kizárólag nyelvtudományi szövegekben írja körül az ortológusok tevékenységét), akkor belátható, hogy valóban nem tesznek különbséget nyelvi szintek között, de nem is tehetnek. Egy nyelvtan megírása, a magyar nyelv szabályszerüségeinek feltérképezése során az író nem lehet tekintettel sem a nyelvi rétegekre, sem az irodalmi müfajok különböző nyelvére. A magyar nyelv nagy grammatikaírási korszakának kezdetén járunk, és a diszciplínák még nem váltak el határozottan egymástól. A litterae fogalmába különböző, mára szétvált tudományterületek tömörülnek, amelyek éppen ebben az időszakban csapódnak ki.

Elképzelhető, hogy a nyelvújításnak ez a korszaka grammatikusok és szépírók vitatkozásaként is értelmezhető. Ez a szempontrendszer érvényesül BENKÖ LORÁND tanulmányában, aki a két tábor mentén képzeli el a viták ütközőpontjait: „A grammatikusok - mint ismeretes - a nyelvi szabályok minél pontosabb megállapításában látták a nyelv megismerésének és előbbre vitelének zálogát; a szépírók a kezüket, tollukat megkötő szabályok ellen lázadnak, a nyelvvel megújító és esztétikailag fölemelő bánásmódra téve a hangsúlyt." (BENKÖ 1989: 389.) A nyelvészek a magyar nyelv szabályszerüségeit keresik, a szépírók a magyar nyelv irodalmi alkotásra való alkalmasságát helyezik előtérbe. És ha a szépírók grammatikusok is egyben - ahogyan KAZINCZY nem -, hát más-más szöveg esetében különbözőképpen járnak el. A két szempontrendszer két diszciplínát választ el egymástól, a nyelvészettudományt és a stilisztikát. Az egyik objektív szabályszerủségek megállapításával írja le a nyelvet, a másik a nyelvi kifejezőerő maximalizálásának kulcsát keresi. A szabályok egységes volta korlátozza az írói nyelvet, és KAZINCZY VERSEGHY nyelvtanát és nyelvészeti törekvéseit szépíróként olvassa. Az irodalmi nyelv autonómiájának áll pártjára, miközben egy szabályozó-tiltó és megtorló intézmény képe lebeg a szemei előtt. 
Csupán néhány bekezdés erejéig kapcsolódik össze a nyomtatott és a kéziratos szöveg. (42-44.) KAZINCZY engedményt tesz VERSEGHYnek: a grammatikai nézeteknek teret enged, és csupán abban határozza meg az ortológia tévedését, hogy minden stílusnemre ki akarják terjeszteni a szabályokat (48.), a nyelv teljes szerkezetére kívánják szabályszerüségeiket kidolgozni (,az Eggység’ Eggységére törekszik, melly egyedűl a' Bölcs' káprázolatiban vagyon-meg"), pedig ez szemben áll a természet rendjével (,,a' Természet mind a' testi mind a' lelki világban a' Külömbözés' Eggysége, a' concordia discors által tenyésztet"). (49., a nyomtatottban: 27.) A komplex grammatikai rendszerekkel szemben ezért védelmezi a szószedeteket (51.), mert azok nem állítanak fel szabályszerüségeket és nem tesznek javaslatot a megalkotott szabályok betartására. Efféle munkával VERSEGHY is, KAZINCZY is, s rajtuk kívül több tucatnyian foglalkoztak (CZIFRA 2015).

3.2. A dolgozat további szakaszai a nyomtatott és a kéziratos szövegben szinte teljesen megegyeznek egymással. (62-73.) A kívánatos német-magyar párhuzam (65-68.) kifejtése ad alapot a tanulmány leggyakrabban idézett mondatainak megfogalmazásához. Ez a nyomtatott tanulmányban is olvasható, de a kéziratos szöveg új értelmezési keretet teremt:

„A' Nyelv ollyan mint az ég' íve a' maga egymásba-futó színeinek gyönyörü játékával. [...] De minthogy ingó alapon semmi nem állhat, szükség, hogy a' Neologiának az az Iskolája, mellyet Füredi Vida Úr gyakorol vádjaival, elmondja a' maga titkát. Imhol vagyon az, fátyol nélkül azoknak, a' kik megérteni tudják, 's itt mondatik, a' mennyire tudnunk lehet, először: »Jól és szépen az ír, a' ki tüzes Orthologus és tüzes Neologus eggyszersmind, 's eggyességben 's ellenkezésben vagyon önmagával.« A' mi Iskolánk' neve tehát nem Neologia, hanem Syncretismus.” (69.)

A sorokat kevesen interpretálták, mivel azok - és maga a tanulmány is - olyannyira homályosan céloznak az értelmezési keretekre, hogy a kéziratos szövegek ismerete nélkül szinte csak az akkori vitapartnerek érthették meg, mire vonatkoznak. Pedig nem állítanak „paradox” szintézis elé (HORVÁTH 1956: 128), sem „mély dialektikával” nem kecsegtetnek (SZAUDER 1965: 279.), ha az ortológia definícióját a többi szövegrész alapján határozzuk meg.

A nyelv sokrétüségében teljes, vagyis léteznek nyelvi rétegek és csoportok. KAZINCZY iskolája kilépett keretei közül, átalakult: immár elismeri a grammatika fontosságát a stílus szabadsága mellett (,tüzes Orthologus és tüzes Neologus eggyszersmind"). Az új irányzat neve szinkretizmus. Ennek elvei szerint a szépíró megteheti mindazt: „a’ mit Erő és Szépség ajánl, a’ minden Nyelvek' ideálja megkíván, a' Magyar Nyelv' természete (örök szokása 's törvénye) világosan nem tilt, a' régibb és újabb Classicusok' által nevelt Ízlés még javasol is, 's a' Szükség múlhatatlanúl parancsol." (69.) Vagyis a szépíróknak helyes esztétikusan (az Erőnek és Szépségnek megfelelve), a magyar nyelv szabályszerüségeinek (amelyet a nyelv természete, a nyelvszokás és a nyelvtörvények határoznak meg) és a klasszikus ízlésnek megfelelve alkotnia és a nyelvet formálnia: amennyiben azt a szükség megköveteli. A nyelvújítás tengelye mentén egymástól elkülönülő irányzatok fölé emelkedő új tábor így gyüjti össze a különböző iskolák magyar nyelv számára hasznos sajátosságait. 
3.3. Ezt követően a neológia hibái a fenti iskoladefiníció alapján kerülnek meghatározásra. (69.) A nyomtatott szöveg ezzel a gondolattal zárul, de a kéziratos változatban (74-101.) még KAZINCZY pályarajza olvasható. Az ifjú írók számára azt javasolja, hogy a klasszikus müveltség és a grammatikai ismeretek megszerzése után fordítsanak idegen nyelvü írásokat előbb a neológia, majd az ortológia iskolája szerint. S miután megtették ezt magyar múvekkel is (86.), vagyis stílusgyakorlatokat végeztek mindkét irányzat szerint, talán be fogják látni, hogy az újítók irányzata alkalmasabb eszközökkel szolgál a szépirodalom számára.

A végső bekezdés előtt, amely a folyóiratban és a kéziratban is nagyjából azonos, a kéziratos dolgozat esetében kitekintést kapunk az ortológusok és neológusok vitájának kimenetelére nézve. Egyikük sem fog nyerni, ,,veszteni fog mind a' két fél, 's a' pálmát a' Syncretismus kapja-el, a' mint illik, 's igy hosszas rezgéseink után rá akadunk azon Eggységre, mellyet némellyek hatalom és erőszak által akarnának felállítani”. (97.) A hatalmi szabályozás helyett KAZINCZY a kulturális élet önszerveződését magasztalja. A kulturális élet pezsgése; a könyvnyomtatás, a sajtó, a színjátszás, a Keszthelyi Helikon ünnepségei, a Marczibányi Alapítvány pályázati kiírása (99.), a nemesi családok társadalmi és kulturális szerepvállalása (100.) a magyar nyelv fejlődését hathatósabban szolgálják minden szabályokat hozó társaságnál. Nem csoda tehát, hogy a tanulmány utolsó sorai éppen a vita tisztaságát követelik meg az eszmecserében résztvevőktől.

4. A magyar nyelvújítás és az Orthologus és Neologus... A kéziratos változatban név szerint szerepelnek az ortológusok a nyomtatottal szemben. Szempontunkból lényegtelen, hogy papírra vetésekor KAZINCZY éppen kit gondolt a névtelen írások mögött. Annyi fontos, hogy óvatosságának következtében a nyomtatott tanulmányból kihagyta a direkt referenciákat, és ezáltal kevésbé bipolarizálta a nyelvvel foglalkozók körét. Műve ezáltal hathatott a békülés, a vitazárás gesztusának. A grammatikusok és a szépírók érdekei élesebben válnak el a kéziratos szövegben. Az új Orthologus és Neologus...-ban nyoma sincsen a békülö hangnemnek: a szerző éppen a vitát sürgeti, a nyelvújítási folyamat szabad lefolyását kívánja. Mégsem merném azt állítani, hogy élesebb vitát eredményezett volna, ha ez a szöveg jelenik meg.

Sajnos, ahogyan erre BENKÖ LORÁND felhívta a figyelmet: bár ez a legkutatottabb korszaka a magyar nyelvújításnak, eddig mégis csak részterületeket érintett a vizsgálat (BENKÖ 1989: 383). Pedig a nyelvújítás legeseménydúsabb évtizedeiben sokkal jelentősebb számú szöveg foglalkozott a magyar nyelvvel, mint az a kánonból vagy éppen KAZINCZY müvei alapján sejthető. 1810 és 1830 között félezernél is több elméleti írás, szógyűjtemény, szótárkezdemény, pályázati kírás, pályamunka és recenzió maradt fenn kéziratban és nyomtatásban. A Debreceni Egyetem Klasszikus Magyar Irodalmi Textológiai Kutatócsoportjának honlapján ezeket a szövegeket online elérhetővé tettük egy több szempontú keresést lehetővé tevő portálon (MNyD. 2015).

Az Orthologus és Neologus... ebben a kontextusban is jelentős szövegnek tekinthető. A többi mü viszont arra figyelmeztet, hogy csupán egy szük csoport, a szépírók szempontjainak kifejezője volt egy szintén szük csoporttal, a grammatikusokkal szemben. A tanulmány az elitkultúra és a szépirodalom nyelvét kívánta 
befolyásolni: a „fenntebb stíl” kimüvelése volt a célja. Egy olyan mértékü változás viszont, amely a magyar nyelv életében új fejezetet nyitott, s amelyről tudjuk, hogy nemcsak a müvelt köznyelv, hanem számos szakma nyelvét, illetve tudományterület szókincsét nagyban befolyásolta (NAGY 2009), a többi mü is eszköze volt. A nyelvújítás korpusza szivárványszín, olyan, mint „,az ég íve”. A társadalom széles rétegeinek bevonódásával - szépírók, egyházi személyek, a köznemesség tagjai, mesteremberek, diákok, gazdák és nyomdászok munkája által - valósult meg, KAZINCZY ideáljának megfelelően.

Kulcsszók: nyelvújítás, 19. század, ortológia, neológia.

\section{Hivatkozott irodalom}

BALASSA JózSEF 1904. Bevezetés. In: BALASSA JÓzSEF kiad., Kazinczy és a nyelvújitás. Szemelvények prózai müveiböl. Stampfel Károly, Pozsony-Budapest. 3-6.

BENKÖ LORÁND 1989. Elméleti törekvések a felvilágosodás korának magyar nyelvtudományában. In: CSÁKY, MORITZ - HASELSTEINER, HORST - KLANICZAY TIBOR - RÉDEI KÁROLY szerk., A magyar nyelv és kultúra a Duna völgyében - Die Ungarische Sprache und Kultur im Donauraum. Nemzetközi Magyar Filológiai Társaság, Budapest-Wien. 383-393.

Beregszászi NAgy PÁL 1815. Dissertatio Philologia de Vocabulorum derivatione ac formatione in Lingua Magyarica. Trattner János Mátyás, Pest.

BíRó FERENC 2010. A legnagyobb pennaháború. Kazinczy Ferenc és a nyelvkérdés. Argumentum Kiadó, Budapest.

CZIFrA MARIANN 2013. Kazinczy Ferenc és az ortológusok. Alakok és árnyak az 1810-es évek nyelvújitási mozgalmában. Ráció Kiadó, Budapest.

CZIFRA MARIANN 2015. Szógyüjtemények és szótárkezdemények a nyelvújítás korában. In: KovÁts DÁNIEL szerk., Széphalom. A Kazinczy Ferenc Társaság Évkönyve 25. Kazinczy Ferenc Társaság, Széphalom. 47-54.

CSETRI LAJOS 1990. Egység vagy különbözöség? Nyelv-és irodalomszemlélet a magyar irodalmi nyelvújitás korszakában. Akadémiai Kiadó, Budapest.

DÖMÖTÖR ADRIENN 2003. A nyelvújítás. In: KIEFER FERENC szerk., A magyar nyelv kézikönyve. Akadémiai Kiadó, Budapest. 103-115.

DÖMÖTÖR ADRIENN 2006. A nyelvújítás. In: KIEFER FERENC föszerk., Magyar nyelv. Akadémiai Kiadó, Budapest. 385-400.

FÜREDI VIDA 1818. A' Recensiókról. Tudományos Gyüjtemény 2 (1818. június): 3-32.

GERGYe LÁsZló 1993. Kazinczy Ferenc kéziratos hagyatéka. MTA, Budapest.

HoRVÁtH JÁNOS 1956. A nyelvi törekvések irodalmi kitisztulása. Kazinczy Ferenc. In: HoRvÁth JÁNOS, Tanulmányok. Akadémiai Kiadó, Budapest. 119-136.

KAZINCZY FERENC 1819a. Orthologus és Neologus; nálunk és más Nemzeteknél. Tudományos Gyüjtemény 3 (1819. november): 1-27.

KAZINCZY FERENC 1819b. Orthologus és Neologus; nálunk és más Nemzeteknél. In: Kazinczy Nyelvészeti tanulmányai. Kézirat. MTA Könyvtár és Információs Központ, K631. $34-55$.

KAZINCZY FERENC 2013. In: CZIFRA MARIANN, Kazinczy Ferenc és az ortológusok. Árnyak és alakok az 1810-es évek nyelvújitási mozgalmában. Ráció Kiadó, Budapest. 205-272. 
KazLev. 1907. Kazinczy Ferencz levelezése. Tizenhetedik kötet. 1820. Január 1. - 1821. Deczember 31. Közzéteszi VÁCZY JÁNOS. MTA, Budapest.

MNyD. 2015. A magyar nyelvújítás dokumentumai 1810-1830. Kiad. CzIFRA MARIANN. Szerk. DeBRECZENI ATTILA. Debreceni Egyetemi Kiadó, Budapest. http://deba.uni-[-] deb.hu/deba/nyelvujitas, ill. http://dx.doi.org/10.5484/A_magyar_nyelvujitas_do-[-] kumentumai

NAGY ÁGOTA szerk. 2009. Járomfa, mozvány, nötövény... A nyelvújítás során született szaknyelvünk ,szokott és szokatlan” szavai. Konferencia a Magyar Mezőgazdasági Múzeumban Kazinczy Ferenc születésének 250. évfordulója tiszteletére. Magyar Mezőgazdasági Múzeum, Budapest.

[NÉV NÉLKÜL] 1813. Mondolat. Sok bővitményekkel és eggy kiegészitett ujj-szótárral eggyütt. Angyalbörbe kötve. Eggy Tünet-forint. Kiadó nélkül, Dicshalom.

RUZSICZKY ÉVA 1963. Irodalmi nyelv szókincsünk a nyelvújitás korában Kazinczy tájszóhasználata alapján. Akadémiai Kiadó, Budapest.

[SíPOS JÓZSEF] 1816. Ó és újj magyar, vagy: rövid értekezés, miképpen kelljen az ó magyarsággal az újjat egyesiteni? az az: Miképpen kelljen a régi magyar nyelvet, újj szavak, szóllások és formák által gazdagítani, tsinositani úgy, hogy azt természeti állásából ki ne vegyük? mint némeljek. Trattner János Tamás, Pest.

SzAUDER JÓzSEF 1965. A nyelvújítási harc fordulatai (1811-1819). Kazinczy versei és tanulmányai. In: PÁNDI PÁL szerk., A magyar irodalom története III. 1772-töl 1849-ig. Akadémiai Kiadó, Budapest. 275-281.

SzEMERE GYULA 1974. Az akadémiai helyesírás története (1832-1954). Nyelvészeti tanulmányok 17. Akadémiai Kiadó, Budapest.

TOLCSVAI NAGY GÁBOR 2007. A nyelvi és irodalmi izlésvita nagy, nyilvános szakasza. In: SZEGEDY-MASZÁK MiHÁly - VERES ANDRÁs szerk., A magyar irodalom történetei. 1800-tól 1919-ig. Gondolat Kiadó, Budapest. 40-56.

Tolnai Vilmos 1929. A nyelvújitás. A nyelvújitás elmélete és története. MTA, Budapest. [Verseghy Ferenc] 1816. Analyticae Institutionum Linguae Hungaricae, Par I. Etymologia Linguae Hungaricae, Sectio I. Etymologia Nominum, ac Pronomium. Typis Regiae Universitatis Hungaricae, Budae.

ZSILINSZKY ÉVA 2003. A magyar nyelvújítás. In: GECSŐ TAMÁs szerk., Természetes nyelvek-mesterséges nyelvek. Tinta Kiadó, Budapest. 94-101.

\section{The Hungarian language reform and Kazinczy's second Orthologue and Neologue}

The essay Orthologus és Neologus; nálunk és más Nemzeteknél (Orthologue and Neologue with us and with other nations) is taken to be a major landmark in the history of the Hungarian language reform. This in spite of the fact that Kaziczy had withdrawn it from publication: he wrote a new, extended version instead. This paper investigates (i) why Kazinczy wrote a new essay; (ii) how the two texts differ from one another; and (iii) in what ways the revised version would have influenced the course of the language reform.

Keywords: language reform, 19th century, orthology, neology. 